\title{
BAHASA ANTARA BARISTA DAN PELANGGAN STARBUCKS DI SURABAYA TOWN SQUARE: KAJIAN SOSIOPRAGMATIK
}

\author{
Afwin Sulistiawati \\ afwince@gmail.com
}

\author{
Dewa Made Artha Yogadinata \\ yogadinata9@gmail.com
}

Universitas Airlangga Surabaya

\author{
Terra Bellatrix Aden Nashahta \\ terrabellatrix888@gmail.com
}

\section{Abstrak}

Penelitian ini difokuskan untuk meneliti kalimat yang digunakan oleh barista yang ada di Starbucks Surabaya Town Square kepada pelanggan yang dikaji menggunakan pendekatan sosiopragmatik. Sampel penelitian ini mencakup tuturan bahasa yang telah diperoleh melalui teknik rekam, simak, dan transkripsi. Analisis data yang digunakan yakni metode deskriptif kualitatif yang terdiri atas tiga proses, yakni reduksi data, penyajian data, dan penarikan simpulan. Hasil penelitian yang didapat ialah bahwa tindak tutur dalam dialog yang terjadi antara barista dengan pelanggan baru lebih banyak menggunakan bahasa Indonesia yang standar dan formal, juga tidak ditemui faktor keakraban sehingga maksim yang terlihat hanya maksim pertimbangan. Sedangkan tindak tutur pada dialog antara barista dan pelanggan yang sering datang lebih banyak menggunakan bahasa Indonesia yang tidak formal bahkan menggunakan bahasa daerah (ragam rendah). Maksim yang muncul juga bermacam-macam, yakni maksim kedermawanan, maksim kebijaksanaan, maksim kecocokan, dan maksim penghargaan. Kata kunci: barista, pelanggan, maksim, sosiopragmatik.

\section{PENDAHULUAN}

Pada era globalisasi ini, banyak perusahaan asing yang membuka kantor dan usaha di Indonesia. Di kota-kota besar, seperti Jakarta, Surabaya, banyak dijumpai pusat perbelanjaan (mall) yang di dalamnya banyak merk-merk dagang dari perusaahan asing mulai dari restoran, kafe, merk baju, merk sepatu, merk tas, dan lainnya. Karena banyak merk dagang asing yang memiliki cabang di Indonesia, penelitian sosiopragmatik ini dilakukan di Starbucks yang merupakan salah satu dari merk dagang asing yang bisa dijumpai di beberapa tempat di Surabaya.

Starbucks merupakan kedai kopi yang didirikan pada tahun 1971 di Seattle. Pada tahun 2002 Starbucks mendirikan cabang di Indonesia (Starbucks Coffee Company, 2011). Starbucks telah menerima banyak penghargaan dalam 7 tahun terakhir. Beberapa penghargaan yang diterima oleh Starbucks adalah sebagai berikut; menurut Zagat's Survey of National Chain Restaurant pada tahun 2009-2010 Starbucks merupakan pemenang dari No. 1 Best Coffee dan No. 1 Most Popular Quick Refreshment Chain. Kemudian menurut Human Right Champaign pada tahun 2009-2010 merupakan salah satu dari Best Places to Work for LGBT Equality (Starbucks Coffee Company, 2011).

Karena starbucks merupakan kedai kopi yang banyak dijumpai di kota-kota besar seperti; Jakarta, Bandung, Surakarta, Jogja, Semarang, Surabaya, dan lainnya. Penelitian ini difokuskan untuk meneliti kalimat sapaan yang digunakan oleh barista Starbucks Surabaya Town Square dari segi sosiopragmatik karena Menurut Leech (1983) sosiopragmatik merupakan bagaimana tindak 
tutur tertentu diungkapkan menurut kondisi sosial masyarakatnya. Pemilihan lokasi Starbucks di Surabaya Town Square (selanjutnya disebut Sutos) karena Sutos merupakan mall dengan tempat makan terbesar di Surabaya dan salah satu yang terbesar di Indonesia (Foursquare, 2016).

Sehubungan dengan itu, manusia memerlukan hubungan timbal balik dengan individu lainnya di kehidupan sehari-hari. Maka dari itu, manusia disebut sebagai makhluk sosial. Hubungan timbal balik antarinvidu tersebut erat kaitannya dengan bahasa. Dalam perkembangannya di masyarakat, bahasa mengalami perkembangan karena bahasa bersifat dinamis. Oleh karena itu, dalam menggunakan bahasa pada saat bertutur sebaiknya masyarakat perlu memperhatikan penggunaan bahasa. Di negara Indonesia, masyarakatnya terkenal dengan cara bertutur mereka yang santun. Masyarakat Indonesia selalu menjaga cara berperilaku mereka baik dalam lisan maupun tindakan di depan lawan bicaranya. Di dalam masyarakat, kesantunan bertutur sangat diperhatikan. Pragmatik mengkaji tentang kesantunan bertutur. Secara eksternal, kesantunan berbahasa dibahas secara luas dalam pragmatik. Sedangkan, kesantunan dibahas secara internal dalam kajian semantik. Pada penelitian kali ini, penulis akan membahas tentang kesantunan berbahasa antara barista kafe dan pelanggan di Starbucks Sutos.

Di Starbucks sering kali bahkan selalu dijumpai sapaan sebagai tuturan pertama yang diucapkan oleh barista Starbucks seperti 'Selamat datang di Starbucks'. Barista merupakan seseorang yang bekerja menyajikan kopi yang berbasiskan espresso kepada pelanggan. Kemudian, barista berasal dari bahasa Italia yang berarti pelayan bar dan barista sendiri merupakan posisi yang terhormat. Di outlet, barista merupakan tombak untuk saling berbagi kenikmatan secangkir kopi (Caswell's Coffee All Rights Reserved, 2014).

Selanjutnya, di dalam hal sapaan dan dan tuturan lain untuk berkomunikasi terdapat perbedaan yang dituturkan oleh barista Starbucks kepada pelanggan lama dan pelanggan baru atau pelanggan yang memiliki frekuensi kedatangan tinggi dan rendah. Perbedaan itu terjadi ketika barista Starbucks menyapa dan berdialog dengan pelanggan baru dan pelanggan yang sering datang ke Starbucks Sutos. Hal tersebut yang mendasari penelitian sosiopragmatik ini untuk mengetahui bagaimana kesantunan berbahasa antara barista dengan pelanggan yang ada di Starbucks Sutos.

Berdasar pada judul di muka, rumusan masalah yang akan dibahas dalam penelitian ini adalah bagaimana kesantunan berbahasa antara barista dan pelanggan Starbucks di Surabaya Town Square. Oleh sebab itu, tujuan dari penelitian ini adalah untuk mendeskripsikan kesantunan bahasa yang digunakan oleh barista terhadap pelanggan melalui kajian sosiopragmatik, khususnya kesantunan berbahasa menurut Lakoff dan Leech.

\section{KAJIAN PUSTAKA}

Adabeberapapenelitiyang sudah melakukan penelitian berkaitan dengankesantunan berbahasa. Penelitian pertama dilakukan oleh Nurhayati, Ngusman, dan Nursaid pada tahun 2013 tentang "Kesantunan Berbahasa Jawa di Kalangan Remaja Masyarakat Jawa di Desa Mampun Baru Pamenang Barat Merangin Jambi". Hasil penelitian ini adalah remaja Jawa di Desa Mampun Baru Kecamatan Pamenang Barat Kabupaten Merangin Provinsi Jambi berpura-pura menggunakan tindak tutur yang buruk. Ada enam jenis tindak tutur buruk oleh remaja Jawa, (1) seruan dengan paksa sehingga tidak cocok di maksim kedermawanan, (2) saran dalam kata-kata kasar sehingga tidak cocok dalam maksim 
bijaksana, (3) permintaan dengan paksa sehingga yang tidak cocok dengan maksim kedermawanan, (4) pujian yang tidak sungguh-sungguh sehingga tidak cocok dengan maksim kerendahan, dan (6) teringat dengan orang tua dalam bahasa ngoko sehingga tidak cocok dengan maksim kedermawanan.

Pada penelitian ini terdapat persamaan dengan penelitian terkait di muka, yakni sama-sama membahas kesantunan berbahasa. Namun objek yang diteliti adalah beda, penelitian ini meneliti kesantunan berbahasa pada dialog antara barista Starbucks dengan pelanggan yang ada di sana. Penelitian ini menggunakan teori yang dipaparkan oleh Lakoff (1990) dan menentukan maksim apa yang terdapat pada percakapan tersebut.

Penelitian terkait kedua yang dilakukan oleh Gusriani, Atmazaki, dan Ellya (2012) berjudul Kesantunan Berbahasa Guru Bahasa Indonesia dalam Proses Belajar Mengajar di SMA Negeri 2 Lintau Buo. Dari penelitian tersebut, Gusriani, Atmazaki, dan Ellya menemukan bahwa dalam proses belajar mengajar, tindak tutur direktif menduduki peringkat pertama yaitu $65,71 \%$. Peringkat kedua ialah tindak tutur representatif dengan jumlah prosentasi $15,51 \%$. Peringkat ketiga adalah tindak tutur deklarasi dengan total prosentasi 13,88\%. Peringkat keempat ialah tindak tutur komisif dengan total tuturan 2,86\%. Peringkat kelima ialah tindak tutur ekspresif dengan total prosentasi 2, 04\%. Kemudian, dari kesantunan berbahasa ditemukan bahwa dalam proses belajar mengajar di SMA Negeri 2 hanya ditemukan empat maksim, antara lain maksim kearifan, maksim kedermawanan, maksim pujian dan maksim pemufakatan. Maksim kearifan menempati peringkat pertama dengan total prosentasi 67,13\%. Maksim kedermawanan menduduki peringkat kedua dengan jumlah prosentasi 17,81\%. Maksim pemufakatan menduduki peringkat ketiga dengan total prosentasi $12,79 \%$. Maksim pujian berada peringkat keempat dengan total prosentasi $2.28 \%$.

Persamaan penelitian ini dengan penelitian yang dilakukan oleh Gusriani, Atmazaki, dan Ellya (2012) ialah sama-sama meneliti kesantunan berbahasa namun penelitian ini langsung meneliti tindak tutur yang dilakukan oleh barista dengan pelanggan Starbucks Sutos sebagai objek penelitian sedangkan Gusriani, Atmazaki dan Ellya menggunakan tindak tutur guru pada proses belajar mengajar di SMA Negeri Lintau Buo sebagi objeknya. Penelitian mereka juga menganalisis tentang jenis-jenis tindak tutur yang digunakan selama proses belajar mengajar tersebut, akan tetapi penelitian ini hanya fokus pada kesantunan berbahasa barista Starbucks di Surabaya Town Square dengan pelanggannya.

Persoalan mengenai kesantunan berbahasa dapat dibahas dalam bidang pragmatik dan juga sosial. Kesantunan bahasa itu sendiri, pada dasarnya, merupakan persoalan nilai atau norma (Andianto, 2013: 54). Sebagai nilai atau norma kehadirannya selalu inklusif di dalam praktik penggunaan bahasa dalam wujud sekmen-sekmen percakapan yang dalam pragmatik disebut tindak tutur. Relasi tindak tutur sendiri mencakup dua komponen, yakni komponen verbal (berupa tutur atau tuturan) dan komponen non-verbal (yakni konteks tutur). Dengan demikian, persoalan kesantunan berbahasa ini dapat pula dikaji dengan sosiopragmatik, yakni mengkaji sisi bahasanya melalui kajian pragmatik dan mengkaji sisi sosialnya melalui kajian sosiologi. Beberapa tokoh yang mengemukakan teori kesantunan ialah Leech dan Lakoff.

Bruce Fraser (1990) mengemukakan: "kesantunan adalah properti yang diasosiasikan dengan tuturan dan di dalam hal ini menurut pendapat si lawan tutur, bahwa si penutur tidak melampaui hakhaknya atau tidak mengingkari dalam memenuhi kewajibannya". Sedangkan Brown dan Levinson 
(1979) mengemukakan: “teori kesantunan berbahasa itu berkisar atas ancaman muka". Bagi Fraser (1978) kesantunan adalah properti yang diasosiasikan dengan tuturan dan di dalam hal ini menurut pendapat si lawan tutur, bahwa si penutur tidak melampaui hak-haknya atau tidak mengingkari dalam memenuhi kewajibannya. Sedangkan penghormatan adalah bagian dari aktifitas yang berfungsi sebagai sarana simbolis untuk menyatakan penghargaan secara regular. Jadi, kalau seseorang tidak menggunakanbahasa sehari-harikepadaseorangpejabatdikantornya,makaorangitutelahmenunjukan hormat, menurut Fraser belum tentu berprilaku santun karena kesantunan adalah masalah lain.

Brown dan Levinson (1979), mengatakan teori kesantunan berbahasa itu berkisar atas ancaman muka (face). Semua orang yang rasional punya muka (dalam arti kiasan tertentu); dan muka itu harus dijaga, dipelihara, dan sebagainya. Ungkapan-ungkapan dalam bahasa Indonesia seperti kehilangan muka, menyembunyikan muka, menyelamatkan muka, dan mukanya jatuh, mungkin lebih bisa menjelaskan konsep muka ini dalam kesantunan berbahasa. Muka ini harus dijaga, tidak boleh direndahkkan orang. Brown dan Levinson mengatakan muka itu ada dua segi yaitu muka negatif dan muka positif. Muka negatif itu mengacu pada citra diri setiap orang yang rasional yang berkeinginan agar ia dihargai dengan jalan membiarkannya bebas melakukan tindakan atau membiarkannya bebas sesuatu dari keharusan mengerjakannya sesuatu.

Bila tindak tuturnya bersifat direktif (misalnya perintah atau permintaan) yang terancam adalah suka negative.Hal ini karena dengan memerintah atau meminta seseorang melakukan sesuatu, kita sebenarnya telah menghalangi kebebasanya untuk melakukan (bahkan untuk menikmati tindakanya). Misalnya, jika meminta tolong seseorang yang sedang asyik melakukan kegiatannya sendiri. Ini sama artinya dengan tidak membiarkannya melakukan dan menikmati kegiatannya itu. Tergantung kepada siapa dia ini dan juga kepada bentuk ujaran yang kita gunakan,orang itu dapat kehilangan muka. Mukanya terancam, dan muka yang terancam itu adalah muka negatif.

Sedangkan yang dimaksud dengan muka positif adalah sebaliknya, yakni mengacu pada citra diri setiap orang yang rasional, yang berkeinginan agar yang dilakukannya,apa yang dimilikinya atau apa yang merupakan nilai-nilai yang ia yakini, sebagai akibat dari apa yang dilakukan atau dimilikinya itu,diakuioranglainsebagaisuatuhalyangbaik,yangmenyenangkan,yangpatutdihargai,danseterusnya. Menurut Brown dan Levinson (1978) sebuah tindak tutur dapat merupakan ancaman terhadap muka.

Tindak tutur seperti ini oleh Brown dan Levinson disebut sebagai Face Threatening Act (FTA) untuk mengurangi kekerasan ancaman itulah di dalam berkomunikasi kita tidak harus selalu menaati. Brown dan Levinson (1978) juga mengusulkan untuk menghindarkan ancaman terhadap muka itu,caranya penutur harus "memperhitungkan" derajat keterancaman sebuah tindak tutur (yang akan ia tuturkan) dengan mempertimbangkan di dalam situasi yang biasa, faktorfaktor (1) jarak sosial di antara penutur dan lawan tutur; (2) besarnya perbedaan kekuasaan atau dominasi di antara keduanya; dan (3) status relatif jenis tindak tutur di dalam kebudayaan yang bersangkutan (artinya, ada tindak tutur orang di dalam suatu kebudayaan di anggap tidak terlalu mengancam muka dan sebagainya). Lalu berdasarkan perkiraan itu, si penutur memilih strategi.

Lakoff (1990: 34) menjelaskan bahwa kesantunan adalah suatu sistem hubungan antar manusia yang diciptakan untuk mempermudah hubungan dengan meminimalkan potensi konflik dan perlawanan yang melekat dalam segala kegiatan manusia. Menurut Lakoff, 
suatu tindak tutur dianggap santun apabila memenuhi tiga kaidah, yakni (1) tidak terkesan memaksa atau angkuh terhadap pendengar (mitra tutur), yang disebut sebagai kaidah formalitas, (2) memberi kesempatan mitra tutur menentukan pilihan, yang disebut sebagai kaidah hesitansi, dan (3) membuat penutur senang sebagai sesama teman, sebagai kaidah equalitas atau kamaraderi. Hal tersebut dapat dikuatkan juga dengan rumusan Lakoff berikut. Lakoff (1990) merumuskan formula kesantunan berbahasa dengan mendasarkan diri pada pragmatic competance melalui dua unsur, yakni unsur be clear dan be polite. Unsur be clear dilandasi prinsip kerja sama Grice, yang meliputi: (1) maxim quantity: memberi informasi yang secukupnya sesuai dengan kebutuhan, (2) maxim quality: mengatakan apa yang diyakini benar, (3) maxim relevan: informasi disampaikan relevan, (4) maxim manner: tidak mengandung ketaksaan informasi. Unsur be polite meliputi (1) tidak menekan mitra tutur (don't be impose), (2) memberi pilihan (give option), (3) menunjukkan keramahtamahan dan akrab.

Leech (1983) juga mencantumkan beberapa maksim terkait dengan kesantunan, antara lain; maksim kebijaksanaan (tact maxim), maksim kedermawanan, maksim penghargaan, maksim kesederhanaan, maksim kecocokan, maksim kesimpatian, dan maksim pertimbangan. Maksim kebijaksanaan ialah penutur meminimalkan keuntungan untuk dirinya sendiri dan memaksimalkan keuntungan untuk pihak lain dalam kegiatan berbicara. Maksim kedermawanan memiliki prinsip yang sama dengan maksim kebijaksanaan, yakni penutur meminimalkan keuntungan untuk dirinya. Maksimpenghargaan ialah penuturmemaksimalkan penghargaan atau pujian ke lawan bicara. Maksim kesederhanaan ialah penutur bersikap rendah hati dengan cara meminimalkan pujian ke diri sendiri. Maksim kecocokan ialah peserta tutur dapat saling menemukan kecocokan ketika mereka sedang di dalam kegiatan bertutur. Maksim kesimpatian ialah memaksimalkan simpati penutur ke lawan bicara dan meminimalkan antipati kepada lawan bicara. Maksim pertimbangan ialah minimalkan rasa tidak senang terhadap lawan bicara dan maksimalkan rasa senang kepada lawan bicara. Teori kesantunan dari Lakoff dan Leech inilah yang menjadi dasar analisis terhadap data-data dalam penelitian ini.

\section{METODE PENELITIAN}

Penelitian ini menggunakan pendekatan kualitatif yang dilakukan di Starbucks Sutos dalam percakapan yang dilakukan oleh barista dengan pelanggan Starbucks ketika berinteraksi. Penelitian kualitatif menurut Moleong (2007:6) adalah penelitian yang bermaksud untuk memahami fenomena tentang apa yang dialami oleh subjek penelitian misalnya perilaku, persepsi, motivasi, tindakan, tuturan, dan lainnya secara holistik, dan dengan cara deskripsi dalam bentuk katakata dan bahasa, pada suatu konteks khusus yang alamiah dan dengan memanfaatkan berbagai metode alamiah. Kemudian, Dornyei (2007) menjelaskan bahwa salah satu karakteristik dari penelitian kualitatif ialah analisis interpretasi. Sehingga, penelitian ini nantinya menggunakan interpretasi yang berasal dari pemikiran penelitiuntukmenginterpretasikan data. Untukpengambilan data dalampenelitian ini, pertamapeneliti memilih populasi karakteristik kesantunan berbahasa antara barista dan pelanggan Starbucks Sutos dalam berinteraksi. Peneliti memilih Starbucks yang berada di Sutos karena Sutos merupakan mall dengantempatmakanterbesardiSurabayadan salahsatuyangterbesardi Indonesia(Foursquare, 2016). Sampel penelitian ini mencakup data wacana atau tuturan bahasa yang telah 
diperoleh melalui teknik rekam, simak dan transkripsi. Di dalam penelitian ini, peneliti melakukan teknik rekam percakapan antara barista dengan pelanggan Starbucks. Setelah mendapatkan rekaman percakapan antara barista dengan pelanggan Starbucks, peneliti menyimak hasil rekaman tersebut dan melakukan transkripsi. Selain itu penelitian ini juga menggunakan teknik wawancara. Patton (yang dikutip dalam Marshal dan Rossman, 1995) menjelaskan bahwa salah satu teknik wawancara dalam metode kualitatif ialah wawancara dengan melakukan pembicaran informal (informal conversational interview). Di dalam penelitian ini, peneliti menggunakan teknik wawancara informal kepada barista Starbucks Sutos. Hal ini dilakukan untuk mengetahui intensitas kedatangan pelanggan sehingga dapat diketahui bagaimana hubungan keakraban antara barista dengan pelanggan.

Kemudian untuk analisis data, peneliti menggunakan metode deskriptif kualitatif yang terdiri atas tiga proses yakni reduksi data, penyajian data, dan analisis interpretasi. Setelah mendapatkan transkripsi keseluruhan data percakapan antara barista Starbucks Sutos, penulis melakukan reduksi data yang terkait dengan kesantunan berbahasa barista Starbucks Sutos dengan pelanggannya. Hal ini dilakukan karena peneliti memfokuskan penelitian terhadap kesantunan berbahasa yang dilakukan barista Starbucks Sutos dengan pelanggannya. Setelah melakukan reduksi data, peneliti menyajikan data tersebut di dalam bab analisa. Setelah data tersebut disajikan di dalam bab analisa, peneliti menggunakan teori kaidah kesantunan milik Lakoff (1990) dan Leech (1983) untuk dasar peneliti dalam menginterpretasikan data tersebut.

\section{ANALISIS}

Data 1

Barista : : "Selamat datang di Starbucks. Silakan, Kak. Mau pesan apa?"

Pelanggan :"Aku mau Dry Cappucino Decau satu."

Barista : : "Ukurannya apa, Kak? Tall, grande, atau venti?

Pelanggan : "Venti"

Barista : "Minum sini atau dibawa pulang, Kak? Mau cake-nya juga? Ini ada dua varian menu cake baru, loh." (sambil menunjuk ke arah kue yang dimaksud)

Pelanggan : :"Oh enggak kak. Ini aja. Dibawa pulang."

Barista : "Atas nama siapa ini, Kak?"

Pelanggan : "Andini."

Barista : : "Baik, Kak. Ditunggu sebentar ya."

Pada percakapan di data 1, dapat dilihat bahwa ketiga kaidah menurut Lakoff dapat terpenuhi, yakni (1) tidak terkesan memaksa atau angkuh terhadap pendengar (mitra tutur), barista menyapa pelanggan yang datang dengan ramah dan kemudian ia menanyai perihal pesanan, (2) memberi kesempatan mitra tutur menentukan pilihan, ketika barista menanyai apa yang akan dipesan oleh pelanggan, barista juga mengenalkan beberapa menu yang kemungkinan belum dikenal oleh pelanggan, hal tersebut dapat dikatakan sebagai pemberian pilihan kepada mitra tutur, dan (3) membuat penutur senang sebagai sesama teman, yakni ketika barista berbicara 
dengan berusaha membuat pelanggan nyaman, berbicara pelan, dan dengan menggunakan bahasa Indonesia formal dengan pilihan kata yang baik dengan tujuan menghargai pelanggannya.

Hal tersebut juga dapat dikaitkan dengan nilai sosial atau faktor relasinya, yakni dengan siapa penutur berbicara akan menentukan bagaimana kesantunan berbahasa si penutur. Karena si pelanggan adalah merupakan pelanggan yang intensitas kedatangannya tidak sering maka barista cenderung tidak kenal dengan si pelanggan. Hal itu terlihat dari bagaimana barista bertutur. Ia menyapa tanpa menyebut nama dan perihal apapun masih perlu bertanya dan seolah si barista belum tahu sama sekali mengenai pelanggan yang sedang diajaknya bicara. Barista pun mengenalkan menu-menu yang dirasa perlu disebutkan utuk memastikan bahwa si pelanggan mengetahui menu-menu Starbucks.

Dialog di atas juga mengandung maksim menurut Leech, yakni maksim pertimbangan, maksudnya ialah meminimalkan rasa tidak senang terhadap lawan bicara dan maksimalkan rasa senangkepadalawanbicara. Beristabersikapterusramahdanseolah-olahsenangdenganpelanggan dengan cara melayani proses jual beli yang menyenangkan. Meskipun pelanggan hanya menjawab dengan jawaban singkat-singkat dan cenderung pasif, barista terus menanyainya dengan hal-hal sesuai dengan topik pembicaraan pada proses jual beli. Berbeda dengan data kedua berikut ini. Data 2

Barista: "Selamat datang di Starbucks. Halo, Kak Jojo. Tumben sendirian aja. Mau pesan apa, Kak Jo?"

Pelanggan : "Hehe iya temen-temen entar nyusul. Aku mau Medium Classic Chocolate satu sama Tuna Puff satu, ya! Eh Si Alfi mana? Kok aku ngga pernah lihat, ya!"

Barista : "Dia akhir-akhir ini sip pagi terus, Kak Jo. Ini keep dulu kayak biasanya atau langsung ini, Kak?"

Pelanggan : "Sini aja lah, mau ngerjain tugas."

Barista : "Wah Kak Jo keren ya, nugas terus. Hehe. Ok, Kak Jo. Ditunggu, ya!" Pelanggan : "Ah kamu bisa aja."

Dari percakapan pada data kedua ini, nilai keakraban sudah terasa sejak dialog pertama yang diucapkan oleh barista. Ia langsung menyapa pelanggan dengan menyebut namanya. Hal tersebut terlihat lebih sopan dan lebih menghargai lawan tutur. Lawan tutur pun akan merasa lebih nyaman dan senang ketika disapa dengan menyebut nama, apalagi secara tidak langsung barista telah memperhatikan kebiasaan pelanggan melalui tuturannya "Tumben sendirian aja." Nilai keakraban macam itu terlihat karena adanya faktor relasi, dengan siapa penutur bicara atau siapa lawan tuturnya, yakni pelanggan yang datang yang bernama Jojo adalah pelanggan yang memiliki intensitas kedatangan tinggi atau sering. Dengan begitu terlihat berbeda cara menyapa dan bertutur barista dan pelanggan pada Data satu dan Data dua.

Data kedua ini juga memenuhi kaidah Lakoff, yakni (1) tidak terkesan memaksa atau angkuh terhadap pendengar (mitra tutur), meskipun barista sudah hafal dengan kebiasaan pelanggannya, ia tetap menanyai perihal apa yang akan dipesan oleh pelanggan, (2) memberi kesempatan mitra tutur menentukan pilihan, seakrab apapun barista dengan pelanggan, 
barista tetap meghargai pilihan pelanggan dan memberi kesempatan untuk memilih sendiri apa yang akan dipesan, dan (3) membuat penutur senang sebagai sesama teman, meskipun di antara keduanya sudah akrab, prosedur yang harus dilakukan si barista tetap dijalankan dengan baik dan benar, yakni barista tetap berbicara dengan sopan dengan tidak menggunakan nada tinggi dan meminta pelanggan untuk menunggu sebentar ketika pesanan sedang diproses.

Dialog di muka juga mengandung maksim-maksim menurut Leech, yakni maksim penghargaan, penutur memaksimalkan penghargaan atau pujian ke lawan bicara. Hal tersebut terlihat pada tuturan barista kepada pelanggannya: "Wah Kak Jo keren ya, nugas terus. Hehe. Ok, Kak Jo. Ditunggu, ya!”. Barista menghargai dan memuji apa yang sudah dilakukan pelanggan dan pelanggan pun menerima pujiannya. Selain itu, maksim lain yang dapat terlihat adalah maksim kecocokan, peserta tutur dapat saling menemukan kecocokan ketika mereka sedang di dalam kegiatan bertutur. Ketika barista dan pelanggan yang bernama Jojo itu bertutur, mereka samasama saling menikmati dengan adanya percakapan dua arah, yakni keduanya saling bertanya dan menjawab. Hal tersebut merupakan salah satu bukti kenyamanan interaksi antara penutur dan petutur.

Data 3

Barista : "Selamat datang di Starbucks, mau minum apa, Kak?"

Pelanggan : "Vanilla Latte."

Barista : "Ukurannya apa, Kak?"

Pelanggan : "Venti."

Barista : "Atas nama siapa, Kak?"

Pelanggan : "Nina."

Barista : : "Baik, ditunggu ya, Kak."

Dari percakapan yang terjadi pada data ketiga ini terjadi antara barista Starbucks dan pelanggan baru yang intensitas kedatangannya tidak sama dengan pelanggan yang sering datang ke Starbucks Sutos. Percakapan di data ketiga sudah menunjukkan tingkat formalitas yang tinggi. Hal tersebut terlihat dari bahasa yang digunakan oleh barista Starbucks Sutos sesuai dengan bahasa Indonesia yang baku. Selain itu percakapan tersebut tidak menunjukkan adanya kedekatan jarak antara barista dengan pelanggan. Kemudian dapat dilihat bahwa ketiga kaidah menurut Lakoff dapat terpenuhi, yakni (1) tidak terkesan memaksa atau angkuh terhadap pendengar (mitra tutur), barista menyapa pelanggan yang datang dengan ramah dan kemudian ia menanyai tentang pesanan atau produk apa yang ingin dia beli, (2) memberi kesempatan mitra tutur menentukan pilihan, ketika barista menanyai apa yang akan dipesan oleh pelanggan, lalu pelanggan langsung menentukan produk yang akan dipesan, meskipun barista tidak mengenalkan produk ke pelanggan tapi dengan melihat daftar menu yang terdapat di Starbucks membuat pelanggan dapat menentukan pilihannya, dan (3) membuat penutur senang sebagai sesama teman, yakni ketika barista berbicara dengan berusaha membuat pelanggan nyaman, berbicara pelan, dan dengan menggunakan bahasa Indonesia formal dengan pilihan kata yang baik dengan tujuan menghargai pelanggannya.

Percakapan pada data ketiga ini terdapat salah satu maksim yang sesuai dengan maksim yang dipaparkan oleh Leech. Maksim tersebut adalah maksim pertimbangan, karena pada saat pengambilan data sikap dari pelanggan tersebut juga diamati oleh peneliti. Meskipun 
sikapnya terkesan angkuh tapi barista mencoba untuk membuat pelanggan tetap merasa nyaman dan tidak menghiraukan keangkuhannya, malah terus bersikap ramah dan selalu senyum. Data 4

Barista : : Halo, Ko Ryan. Selamat datang di Starbucks. Sendirian aja, Ko?"

Pelanggan : :'Iya, dewean aku. Bosen dirumah."

Barista : :Mau minum apa? Biasanya ta, Ko?"

Pelanggan : "Iya, biasae ae."

Dari percakapan yang terdapat pada data keempat ini berbeda dengan percakapan yang terdapat pada data ketiga atau sebelumnya. Jika percakapan pada data ketiga suasana yang terjadi sangat formal, maka pada data keempat ini terjadi suasana yang begitu akrab seperti teman biasa. Barista langsung bisa mengakrabkan diri dengan pelanggan yang intensitas kedatangannya ke Starbucks sangat tinggi. Artinya, pelanggan pada data keempat ini sering datang ke tempat tersebut sehingga barista yang ada di sana sudah kenal dan akrab dengan dia bahkan hafal dengan bagaimana kebiasaannya. Bahasa yang digunakan juga tidak seperti data ketiga yang saangat formal.

Jika dilihat dengan ketiga kaidah menurut Lakoff, kaidah-kaidah tersebut dapat terpenuhi, yakni (1) tidak terkesan memaksa atau angkuh terhadap pendengar (mitra tutur), barista menyapa pelanggan yang datang dengan ramah memulai percakapan layaknya teman yang sudah mempunyai jarak kedekatan dan kemudian ia menanyakan pesanan atau produk apa yang ingin dia beli, (2) memberi kesempatan mitra tutur menentukan pilihan, ketika barista menanyai apa yang akan dipesan oleh pelanggan, lalu pelanggan langsung menentukan produk yang akan dipesan, walaupun barista sudah hafal dengan pesanan yang biasa dipesan tetapi barista tersebut tetap harus memberikan penawaran pilihan produk apa yang akan dipesan oleh pelanggan tersebut, dan (3) membuat penutur senang sebagai sesama teman, yakni ketika barista berbicara dengan berusaha membuat pelanggan nyaman, dan dengan menggunakan bahasa Indonesia yang tidak terlalu formal karena barista tersebut sudah sering bertemu dengan pelanggan. Kemudian, jika dilihat dari enam maksim yang dipaparkan oleh Leech, percakapan tersebut mempunyai unsur maksim pemufakatan atau kecocokan. Hal ini terlihat pada kalimat: Barista : : Halo, Ko Ryan. Selamat datang di Starbucks. Sendirian aja, Ko?”

Pelanggan : "'Iya, dewean aku. Bosen dirumah."

Dari percakapan tersebut menunjukkan bahwa antara barista dan pelanggan saling membina kecocokan atau kesetujuan dalam kegiatan bertutur tersebut. Percakapan di atas terlihat adanya kecocokan antara barista dan pelanggan dengan menggunakan bahasa yang tidak terpaku pada aturan, bahkan pelanggan menjawabnya dengan menggunakan bahasa daerah yang merupakan ragam bahasa rendah, yakni bahasa Jawa. Pelanggan menyatakan bahwa dia memang datang sendiri ke Starbucks dan sedang bosan di rumah. Pelanggan dengan santainya membicarakan masalahnya kepada barista karena adanya kecocokan antarkeduanya. Data 5

Barista : : "Selamat datang di Starbucks, Kak. Silakan! Mau pesan minuman apa?"

Pelanggan : "Green Tea."

Barista : : "Ukurannya apa, Kak? Mau tall, grande, atau venti, Kak?” 
Pelanggan : "Tall"

Barista : :Kuenya gak sekalian, Kak? Kita ada varian baru loh."

Pelanggan : "Enggak deh, itu aja dulu."

Barista : "Atas nama siapa minumannya, Kak?"

Pelanggan : "Jeje."

Apabila kita lihat dari data percakapan antara barista Starbucks dan pelanggan baru atau yang tidak sering datang ke Starbucks Sutos maka kita akan melihat bahwa dalam percakapan tersebut barista Starbucks menggunakan bahasa Indonesia yang formal, dan terjadi jarak antara barista Starbucks dengan pelanggan tersebut. Komunikasi mereka hanya sekadar antara penjual dan pembeli tidak ada keakraban antara barista dengan pelanggan baru. Apabila kita lihat berdasarkan ketiga kaidah dari Lakoff semuanya dapat terpenuhi. Pertama, tidak ada kesan memaksa ataupun angkuh terhadap pelanggan yang mana pada data ini sebagai pendengar (mitra tutur). Barista menyapa pelanggan yang datang dengan ramah, kemudian barista menanyakan pesanan dari pelanggan.

Kedua, memberikan kesempatan dari mitra tutur untuk menentukan pilihan. Barista menanyakan pilihan minuman yang akan dibeli oleh pelanggan, barista juga menawarkan kue kepada pelanggan. Ketiga, membuat penutur senang sebagai teman, yakni barista berusaha membuat pelanggan merasa nyaman dengan menggunakan bahasa Indonesia formal dan berbicara pelan kepada pelanggan. Jika dilihat dari faktor sosial, barista bersikap sopan dengan pelanggan karena pelanggan tersebut merupakan pelanggan yang intensitas kedatangannya tidak sering datang ke Starbucks Sutos. Hal ini menjadikan komunikasi antara barista dan pelanggan tidak terlihat akrab.

Pada data di atas apabila dianalisis menggunakan maksim dari Leech, maka aka ditemukan maksim pertimbangan. Maksim pertimbangan ialah minimalkan rasa tidak senang terhadap lawan bicara dan memaksimalkan rasa senang kepada lawan bicara. Pada dialog di atas juga dapat ditemukan maksim pertimbangan, barista Starbucks menanyakan pesanan pelanggan sesuai dengan prosedur perusahaan mereka dan pelanggan menjawab hal tersebut dengan singkat, barista Starbucks Sutos tetap melayani pelanggan tersebut dengan keramahan dan kebaikan. Data 6

Barista : : "Selamat datang di Starbucks, Ce Sisley. Kok lama gak kesini? Tadi Ce Chloe kesini loh."

Pelanggan : "Loh iya tah? Gak ngomong loh dia, eh aku mau Classic Chocolate sama Peanut Butter Panini, Ya. Kuenya take away aja."

Barista : "Siap, Ce. Mau bayar pake apa ini Starbucks card, debit, atau cash?"

Pelanggan : "Debit aja."

Jika melihat percakapan barista Starbucks dengan pelanggan lama, maka pecakapan tersebut berubah menggunakan bahasa informal, dan barista menyebutkan nama dari pelanggan tersebut. Kemudian terjadi keintiman dalam komunikasi mereka yang tidak menunjukkan jarak antara penjual dan pembeli. Barista tersebut juga memberikan informasi bahwa teman dari Ce Sisley yang bernama Ce Chloe baru saja dari Starbucks juga. Selain itu, pelanggan menyebutkan nama minuman dan makanannya serta memintanya untuk dikemas dengan rapi karena dia tidak akan meminum dan memakannya di Stabucks. Barista juga menawarkan berbagai macam 
pilihan untuk membayar, hal ini menunjukkan keakraban dari pelanggan lama dan barista tersebut karena barista telah mengetahui bagaimana kebiasaan pembayaran si pelanggan.

Apabila dikaji melalui tiga kaidah Lakoff maka dialog di muka telah memenuhi ketiga kaidah tersebut, yakni pertama, tidak berkesan memaksa atau angkuh terhadap pendengar (mitra tutur), meskipun barista telah hafal dengan teman dari pelanggan lama, barista tersebut memberikan keterangan bahwa teman dari pelanggan yang bernama Ce Chloe baru saja berkunjung ke Starbucks Sutos, barista juga memberikan pilihan berbagai macam pembayaran kepada pelanggan meskipun barista tersebut telah hafal cara pembayaran yang akan dipilih oleh pelanggan.

Kedua, memberikan kesempatan mitra tutur menentukan pilihan, pada data ini pelanggan telah menyebutkan keinginannya untuk jenis pesanan yang telah ditentukannya, kemudian barista juga memberikan pilihan kepada pelanggan untuk pembayarannya. Ketiga, membuat penutur senang sebagai sesama teman yang telah kenal sehingga antara barista dengan pelanggan telah akrab namun barista tetap bersikap sopan dengan menggunakan keramahan dengan mengatakan bahwa pelanggan yang bernama Ce Sisley telah lama tidak berkunjung ke Starbucks Sutos dan memberi tahu bahwa temannya baru saja dari Starbucks Sutos.

Jika analisis data 6 menggunakan maksim yang dikemukakan oleh Leech, maka akan ditemukan maksim kebijaksanaan dan kedermawanan. Maksim kebijaksanaan dan maksim kedermawanan yang dapat ditemukan ialah barista menyampaikan informasi bahwa teman dari Ce Sisley yang bernama Ce Chloe baru saja berkunjung dari Starbucks Sutos. Barista memaksimalkan keuntungan kepada pelanggan dengan menyampaikan informasi tersebut yang sebenarnya tidak memberikan keuntungan apapun kepada barista sendiri. Data 7

Barista : Selamat datang di Starbucks, silakan, Kak! Mau pesan apa minumnya?

Pelanggan : Hemm.. aku mau hot tea aja.

Barista : Untuk tea-nya mau apa, Kak? Ada earl grey, english breakfast, chai, mint citrus, dan mint blend. Kakaknya mau pilih yang mana?

Pelanggan : Hmmm.. mint citrus aja.

Barista : : Ukurannya mau apa, Kak? Ada tall, grande, dan venti?

Pelanggan : Grande aja.

Barista : Atas nama siapa minumannya, Kak? Kuenya nggak sekalian, Kak?

Pelanggan : Enggak, itu dulu aja. Afif, Mas.

Barista : Baik, silakan ditunggu sebentar ya, Kak.

Berdasarkan data pada data 7, dapat kita lihat bahwa ketiga kaidah kesantunan milik Lakoff (1990) telah terpenuhi, antara lain tidak ada kesan memaksa atau angkuh yang dilakukan oleh barista terhadap pelanggan. Dalam data tersebut, dapat kita lihat bahwa barista menanyakan perihal pesanan pelanggan. Kedua, barista memberikan kesempatan terhadap pelangga untuk menentukan pilihan. Di data tersebut, dapat dilihat bahwa barista menawarkan macam teh yang dimiliki oleh Starbucks dan juga pilihan tentang ukuran untuk minumannya serta menawarkan apakah ingin membeli kue sekalian atau tidak. Ketiga, dapat kita ketahui bahwa barista membuat dirinya senang sebagai sesama teman dengan pelanggan. Dapat 
dikatakan bahwa barista menggunakan bahasa Indonesia yang formal dan berusaha membuat pelanggan nyaman dengan berbicara yang pelan yang bertujuan untuk menghargai pelanggan.

Apabila dikaitkan dengan maksim milik Leech (1983), dapat ditemukan bahwa dialog tersebut adalah maksim kebijaksanaan, maksim kedermawanan, dan maksim pertimbangan. Seperti yang telah dijelaskan sebelumnya, maksim kebijaksanaan ialah penutur meminimalkan keuntungan untuk dirinya sendiri dan memaksimalkan keuntungan untuk pihak lain dalam kegiatan berbicara. Kemudian, maksim kedermawanan memiliki pengertian yang sama dengan maksim kebijaksanaan. Dalam dialog tersebut dapat dilihat bahwa barista menawarkan macam teh yang ada di Starbucks. Dalam dialog tersebut, barista meminimalkan keuntungan untuk dirinya ketika dia menjelaskan tentang macam teh untuk pelanggan dan memaksimalkan kepuasan pelanggan yang datang dengan cara menjelaskan pilihan-pilihan menu. Namun, pelanggan mendapatkan keuntungan yakni pelanggan mendapatkan wawasan bahwa teh yang ada di Starbucks tidak hanya satu macam tapi bermacam-macam untuk pelanggan yang menginginkan teh panas.

Seperti yang telah dijelaskan sebelumnya maksim pertimbangan ialah meminimalkan rasa tidak senang terhadap lawan bicara dan memaksimalkan rasa senang kepada lawan bicara. Di dialog tersebut, dapat kita lihat bahwa barista dengan ramah melayani pelanggan dengan menawarkan macam dari teh yang ada di Starbucks meskipun pelanggan hanya membalas ujaran barista dengan singkat-singkat. Kemudian, apabila dikaitkan dengan nilai sosial, dapat diketahui bahwa pelanggan dalam dialog data nomor 7 merupakan pelanggan yang intensitas kedatangannya tidak sering. Hal tersebut terlihat pada bagaimana barista bertutur sapa kepada pelanggan, yakni barista menawarkan macam teh yang ada di Starbucks dan menanyakan nama pelanggan. Data 8

Barista $\quad$ : Selamat datang di Starbucks, Kak! Silakan, mau pesan minum apa, Kak?

Pelanggan : Caramel Machiato

Barista : Ukurannya apa, Kak? Ada tall, grande, atau venti ?

Pelanggan : Seng gede.

Barista : Venti ya, Kak? Atas nama siapa kak minumnya? Kuenya nggak sekalian,Kak?

Pelanggan : Afit, gak wes.

Barista $\quad$ : Baik, Kak. Ditunggu, ya.

Berdasarkan data di atas, dapat dilihat bahwa ketiga kaidah kesantunan milik Lakoff terpenuhi, antara lain; tidak ada kesan memaksa atau angkuh yang dilakukan oleh barista terhadap pelanggan. Barista tidak ada kesan angkuh atau memaksa ketika menanyakan perihal pesanan pelanggan. Kedua, barista memberikan kesempatan terhadap pelangga untuk menentukan pilihan. Barista memberikan pilihan tentang ukuran untuk minuman pelanggan serta menawarkan apakah pelanggan ingin membeli kue juga atau tidak. Ketiga, dapat kita ketahui bahwa barista membuat dirinya senang sebagai sesama teman dengan pelanggan. Dari dialog tersebut dapat diketahui pula bahwa barista menggunakan bahasa Indonesia yang formal meskipun pelanggan menggunakan bahasa Jawa Suraboyoan. Hal ini bertujuan bahwa barista menghargai pelanggan dengan menggunakan bahasa Indonesia yang formal.

Selanjutnya, apabila dikaitkan dengan maksim milik Leech maka akan ditemukan maksim pertimbangan. Maksimpertimbangan di dalam dialog data 8 ialah barista berupaya untuk sopan, santun, 
dan menghargai pelanggan dengan cara menggunakan bahasa Indonesia yang formal ketika melayani pelanggan. Kemudian, apabila dilihat dari nilai sosialnya ialah sikap barista ketika melayani pelanggan dengan menggunakan bahasa Indonesia yang formal dan menanyakan untuk siapa minuman tersebut dibuat menunjukkan bahwa intensitas kedatang pelanggan tersebut sedikit atau jarang ke Starbucks Sutos sehingga menjadikan barista tidak memiliki hubungan yang dekat dengan pelanggan tersebut. Data 9

Barista : Selamat datang di Starbucks, Pak Andre sudah lama lho nggak ke sini. Lho tantenya mana?

Pelanggan : Dia sek liat-liat baju di Minimal, habis ini lak ke sini.

Barista : Mau minum apa ini?

Pelanggan : Aku minta hot cappucino, sama cotton candy.

Barista : Ukurannya mau apa ini, Pak? Kayak biasanya aja tah? Venti?

Pelanggan : Iyo, venti ae.

Barista : Kuenya, Pak? Nggak sekalian tah?

Pelanggan : Iyo aku mau tuna puff sama yang chicken mushroom itu loh.

Barista : : Siap, Pak. Ini pembayarannya mau pakai apa? Debit atau kredit?

Pelanggan : Kredit ae lah kayak biasanya.

Apabila kita lihat berdasarkan ketiga kaidah Lakoff, dari dialog tersebut dapat dilihat bahwa semua kaidahnya terpenuhi. Pertama, diketahui bahwa barista tidak ada kesan memaksa atau angkuh terhadap pelanggan. Hal ini dapat dijumpai ketika barista langsung menyapa pelanggan dengan menggunakan namanya, menanyakan keberadaan istrinya dan pilihan pembayarannya. Kedua, barista memberikan kesempatan pelanggan untuk memilih, yaitu dengan cara menawarkan apakah pelanggan ingin membeli kue atau tidak. Ketiga, barista membuat pelanggan senang dengan cara berusaha ramah dan mengingat kebiasaan pelanggan membeli minuman dengan ukuran venti serta menawarkan dua pilihan pembayaran yang biasa digunakan oleh pelanggan.

Selanjutnya, apabila dikaji melalui teori maksim milik Leech, dapat diketahui bahwa terdapat maksim kedermawanan, maksim kebijaksanaan, maksim kecocokan dan maksim pertimbangan. Untuk maksim kedermawanan dan maksim kebijaksanaan dapat terlihat ketika barista mengatakan bahwa Pak Andre lama tidak datang ke Starbucks dan menyakan tentang istri Pak Andre. Hal ini menunjukkan bahwa barista meminimalkan keuntungan untuk dirinya namun memaksimalkan keuntungan kepada pelanggan dengan cara menunjukkan perhatiannya kepada pelanggannya. Kemudian maksim kecocokan dapat terlihat juga ketika barista menanyakan ukuran minuman pelanggan apakah masih seperti biasanya ketika pelanggan memesan dengan ukuran venti atau mau ukuran yang lainnya dan ketika pelanggan lupa-lupa ingat untuk menyebutkan nama kue yang biasa dia makan. Selanjutnya untuk maksim pertimbangan dapat diketahui bahwa barista berupaya untuk memaksimalkan rasa senang kepada pelanggan dengan menunjukkan perhatiannya kepada pelanggan. Barista menyatakan bahwa pelanggan sudah lama tidak datang ke Starbucks, hal inilah yang menunjukkan maksim pertimbangan dalam dialog tersebut. Selanjutnya apabila dilihat berdasarkan nilai sosialnya maka keakraban antara barista dengan pelanggan tersebut berdasarkan intensitas kedatangan pelanggan ke Starbucks. 
Berdasar kesembilan data dialog antara barista dengan pelanggan Starbucks yang telah dianalisis di muka, hasil penelitian yang didapat ialah bahwa tindak tutur dalam dialog yang terjadi antara barista dengan pelanggan baru lebih banyak menggunakan bahasa Indonesia yang standar dan formal, juga tidak ditemui faktor keakraban sehingga maksim yang terlihat ialah maksim pertimbangan, yakni meminimalkan rasa tidak senang terhadap lawan bicara dan maksimalkan rasa senang kepada lawan bicara. Hal tersebut terjadi antara barista dengan pelanggan karena barista selalu bersikap ramah dan mengupayakan agar pelanggan selalu merasa nyaman berada di Starbucks. Selain maksim pertimbangan pada dialog data ketujuh, dapat ditemukan maksim kebijaksanaan dan maksim kedermawanan. Dalam dialog tersebut barista berupaya meminimalkan keuntungan untuk dirinya dengan menjelaskan macam-macam teh yang dimiliki oleh Starbucks.

Sedangkan pada tindak tutur pada dialog antara barista dan pelanggan yang sering datang lebih banyak menggunakan bahasa Indonesia yang tidak formal bahkan menggunakan bahasa daerah (ragam rendah) karena pelanggan tersebut sering datang ke Starbucks sehingga para barista sudah kenal dan bahkan hafal dengan kebiasaan-kebiasaan pelanggan lamanya dan merasa akrab saat berbicara. Antara barista dengan pelanggan yang intensitas kedatangannya tinggi, mereka melakukan dialog dua arah (saling bertanya dan menjawab) dan pembicaraan mereka pun tak melulu bicara tentang menu dan pemesanan saja, tetapi mereka bisa membicarakan hal lain. Maksim yang muncul juga bermacam-macam, yakni maksim kedermawanan, maksim kebijaksanaan, maksim kecocokan, maksim penghargaan, dan maksim pertimbangan.

Pada dialog yang terjadi, baik antara barista dengan pelanggan yang frekuensi kedatangannya tinggi maupun antara barista dengan pelanggan yang memiliki frekuensi kedatangan rendah, keduanya memenuhi kaidah kesantunan berbahasa menurut Lakoff, yakni (1) tidak terkesan memaksa atau angkuh terhadap pendengar (mitra tutur), yang disebut sebagai kaidah formalitas, (2) memberi kesempatan mitra tutur menentukan pilihan, yang disebut sebagai kaidah hesitansi, dan (3) membuat penutur senang sebagai sesama teman, sebagai kaidah equalitas atau kamaraderi.

\section{SIMPULAN}

Dari hasil temuan penelitian dapat disimpulkan bahwa tindak tutur dalam dialog yang terjadi antara barista dengan pelanggan baru lebih banyak menggunakan bahasa Indonesia yang standar dan formal, juga tidak ditemui faktor keakraban sehingga maksim yang terlihat hanya maksim pertimbangan, yakni meminimalkan rasa tidak senang terhadap lawan bicara dan maksimalkan rasa senang kepada lawan bicara. Sedangkan pada tindak tutur pada dialog antara barista dan pelanggan yang sering datang lebih banyak menggunakan bahasa Indonesia yang tidak formal bahkan menggunakan bahasa daerah (ragam rendah) karena antara barista dengan pelanggan sudah ada keakraban. Maksim yang muncul juga bermacam-macam, yakni maksim kedermawanan, maksim kebijaksanaan, maksim kecocokan, dan maksim penghargaan.

Pada dialog yang terjadi, baik antara barista dengan pelanggan yang frekuensi kedatangannya tinggi maupun frekuensi kedatangan rendah sama-sama memenuhi kaidah kesantunan berbahasa menurut Lakoff, yakni (1) tidak terkesan memaksa atau angkuh 
terhadap pendengar (mitra tutur), yang disebut sebagai kaidah formalitas, (2) memberi kesempatan mitra tutur menentukan pilihan, yang disebut sebagai kaidah hesitansi, dan (3) membuat penutur senang sebagai sesama teman, sebagai kaidah equalitas atau kamaraderi.

\section{DAFTAR PUSTAKA}

Andianto, M. R. (2013). PRAGMATIK: Direktif dan Kesantunan Bahasa. Yogyakarta: Gress Publishing.

Brown, P., \& Levinson, S. C. (1987). Politness: Some Universals In Language Usage. Cambridge: Cambridge University Press.

Caswell's Coffee All Rights Reserved. (2014). BARISTA ADALAH LIFESTYLE. Retrieved from Caswell's Fine Coffees and Teas: http://caswellscoffee.com/events/ibc-jakarta-2013-eksistensidan-konsistensi-seorang-barista/

Dornyei, Z. (2007). Research Methods in Applied Linguistics: Quantitative, Qualitative, and Mixed Methodologies. Oxford: Oxford University Press.

Fraser, B. (1990). Perspectives on politeness. Journal of pragmatics, 14(2), 219-236.

Foursquare. (2016). Surabaya Town Square (SUTOS). Retrieved from Foursquare: https:// foursquare.com/v/surabaya-town-square-sutos/4b482b20f964a5205d4926e3

Gusriani, N., Atmazaki, \& Ellya, R. (2012). Kesantunan Berbahasa Guru Bahasa Indonesia Dalam Proses Belajar Mengajar Di SMA Negeri 2 Lintau Buo. Jurnal Pendidikan Bahasa dan Sastra Indonesia, 287-295.

Lakoff, T. R. (1990). Talking Power: The Politics of Language. Seattle: A Division of Harper Collins Publisher.

Leech, G. (1983). Principles of Pragmatics. London: Longman.

Marshal, C., \& Rossman, G. B. (1995). Designing Qualitative Research. California: Sage Publication, Inc.

Moleong, L. J. (2007). Metodologi Penelitian Kualitatif. Bandung: PT Remaja Rosdakarya Offset. Starbucks Coffee Company. (2011). Starbucks Coffee Recognition . Retrieved from Starbucks: http://www.starbucks.co.id/media/spain-pdf-starbucks-company-recognition_tcm33-10743.pdf Starbucks Coffee Company. (2011). Starbucks Company Timeline. Retrieved from Starbucks: http://www.starbucks.co.id/media/spain-pdf-starbucks-company-timeline_tcm33-10744.pdf Nurhayati, N., Ngusman, N., \& Nursaid, N. (2013). Kesantunan Berbahasa Jawa di Kalangan Remaja Masyarakat Jawa di Desa Mampun Baru Pamenang Barat Merangin Jambi. Pendidikan Bahasa dan Sastra Indonesia, 1(2), 435-443. 